\title{
VALIDITY ANALYSIS OF THE VARK (VISUAL, AUDITORY, READ- WRITE, AND KINESTHETIC) MODEL - BASED BASIC READING AND WRITING INSTRUCTIONAL MATERIALS FOR THE 1ST GRADE STUDENTS OF ELEMENTARY SCHOOL
}

\author{
Mayarnimar', ${ }^{1}$ Taufina ${ }^{2}$ \\ Lecturers of Primary School Teacher Education, the Faculty of Education, State University of Padang \\ Corresponding e-mail: mayar.nimar@yahoo.co.id ${ }^{1}$,taufina_taufik@yahoo.co.id ${ }^{2}$
}

\begin{abstract}
This research aims to produce Lesson Plan and learning materials of Basic Reading and Writing by using VARK (Visual, Auditory, Read-Write, and Kinesthetic) Model in the 1st grade of Elementary School. The development was done on the basis of the students' needs. They were assumed to have low ability in Basic Reading and Writing. To develop the materials, 4D (Define, Design, Develop, and Disseminate) Model was applied. The development focused on the users' needs in accordance with the context (teachers and students) so that a draft containing Standard of Competence, Basic Competence, indicators and learning objectives was produced. The product was revised based on the data of authentic process in accordance with the users' needs (process/formative evaluation). The results of the validation show that the learning materials produced are valid in which the validity score is 3.64 or $90.91 \%$ (very valid).
\end{abstract}

Keywords: $\quad$ Basic Reading and Writing, VARK Model, Elementary School

\section{INTRODUCTION}

The learning process of Basic Reading and Writing is an integral, closely related and identical process to the lower classes of Elementary School. The two skills (reading and writing) are regarded as the basic foundation in achieving the success in other skills. Consequently, Basic Reading and Writing learning process requires special attention from teachers. It concerns with teaching reading and writing skills to the lower classes in Elementary School especially to the 1st grade students. Basic reading and writing skills are highly focused on mastering literacy. At a basic level, learning process of writing put more emphasis on mechanical skills; how to use pencil to form readable words.

To create an effective learning process of Basic Reading and Writing skills, the teachers could not merely rely on their teaching ability but also on the use of appropriate instructional materials. Interesting instructional materials, for example, make the students feel interested and happy to take part in the learning process. Thus, creative teachers should be able to create an effective learning process and use appropriate instructional materials.

Based on the observation conducted from March 21st, 2016 to April 2nd, 2016 in the 1st grade of SD N 01 Sawahan Kota Padang, West Sumatra, it is figured out most of the teachers tended to conduct conventional learning process in which the teachers are the center of the learning. As a result, the teachers did not manage to make use of the students' learning styles which are much varied.

The results of the observation also reveal that the low quality of the learning process is closely related to the instructional materials used by the teachers. The materials could not facilitate the students of various learning styles to experience a meaningful learning process. Similarly, the Lesson Plan designed merely put the students as good listeners and was unlikely to motivate them to be active in the process. This condition then made the students feel discouraged and got unsatisfied learning outcomes. To deal with the problems VARK (Visual, Auditory, Read-Write, and Kinesthetic) model is applied.

VARK model is a new alternative model which was modified by making use of the modality owned by the students. According to [1], VARK is the acronym of four major learning styles, namely Visual, Auditory, Read-Write, and Kinesthetic. It associates the students' experiences to the modality they possess including visual, auditory, reading and writing, and kinesthetic styles. Applying this model, 
at the end of the learning process, the students get rewards for their work for which the teacher and the rest of the class give applause. The teachers also can say "Excellent" or "Good" to boost the students' mentality and motivate the other students to learn, and to create meaningful learning process [2].

Basic Reading, in this research, emphasizes on the process of decoding and recoding the reading mechanically. Meanwhile, Basic Writing is simply defined as a process of producing sounds.

\section{RESEARCH METHOD}

This research was conducted by applying 4D model. According to Sugiyono (2008:404), 4D consists of four phases, namely defining, designing, developing, and disseminating

Defining phase is intended to specify and define the condition fitting to the purpose of this research. In this phase, needs analysis, curriculum analysis, and student analysis were carried out. In designing phase, VARK model - based instructional materials for teaching Basic Reading and Writing skills to the 1st grade students of Elementary school was designed. To design the materials, there are several things that need to be taken into account, including the appropriateness of the materials to the curriculum, the selection of the learning sources, the organization of the materials, the appropriateness of the materials to the time allocated, the readability of the materials, and the presentation of the materials. The developing phase is aimed at producing the instructional materials which had already been revised by the experts. The developing phase includes validity, practicality and effectiveness tests of the instructional materials developed.

A. Data and Data Analysis

The data obtained in this research were in the form of qualitative and quantitative data. The quantitative data were gathered by using questionnaire, observation sheet, and validation sheet. These data then were described qualitatively. The quantitative data were obtained through the implementation of the instructional materials.

\section{B. Technique of Data Analysis}

The data were analyzed by using descriptive quantitative and qualitative techniques. The process of data analysis includes several activities, namely, reducing the data, presenting the data, and drawing conclusions.

\section{Instruments}

The instruments of the research were observation sheet to record the learning activities and the result of interview; documents to file the identification data, assessment data, planning data, and evaluation data; questionnaire to see the experts' responses on the instructional materials developed; and portofolio to record the improvement of the students' Basic Reading and Writing skills after VARK model was applied.

\section{Procedure of the Research}

This research was conducted in two semesters (one year). In the first semester, the researcher carried out needs analysis, curriculum analysis, and student analysis. The results of the analysis then became the basis for designing the initial draft of the VARK Model-based instructional materials for teaching Basic Reading and Writing skills to the 1st students of Elementary School. Subsequently, the instructional materials in the form of Lesson Plan and teaching materials were developed. In the second semester, the practicality and the effectiveness of the products were tested. Having the instructional materials practical and effective, the researcher then disseminate the products in a wide scale..

\section{FINDING AND DISCUSSIONS}


Tabel 5.1: The of Validation on Content Aspect

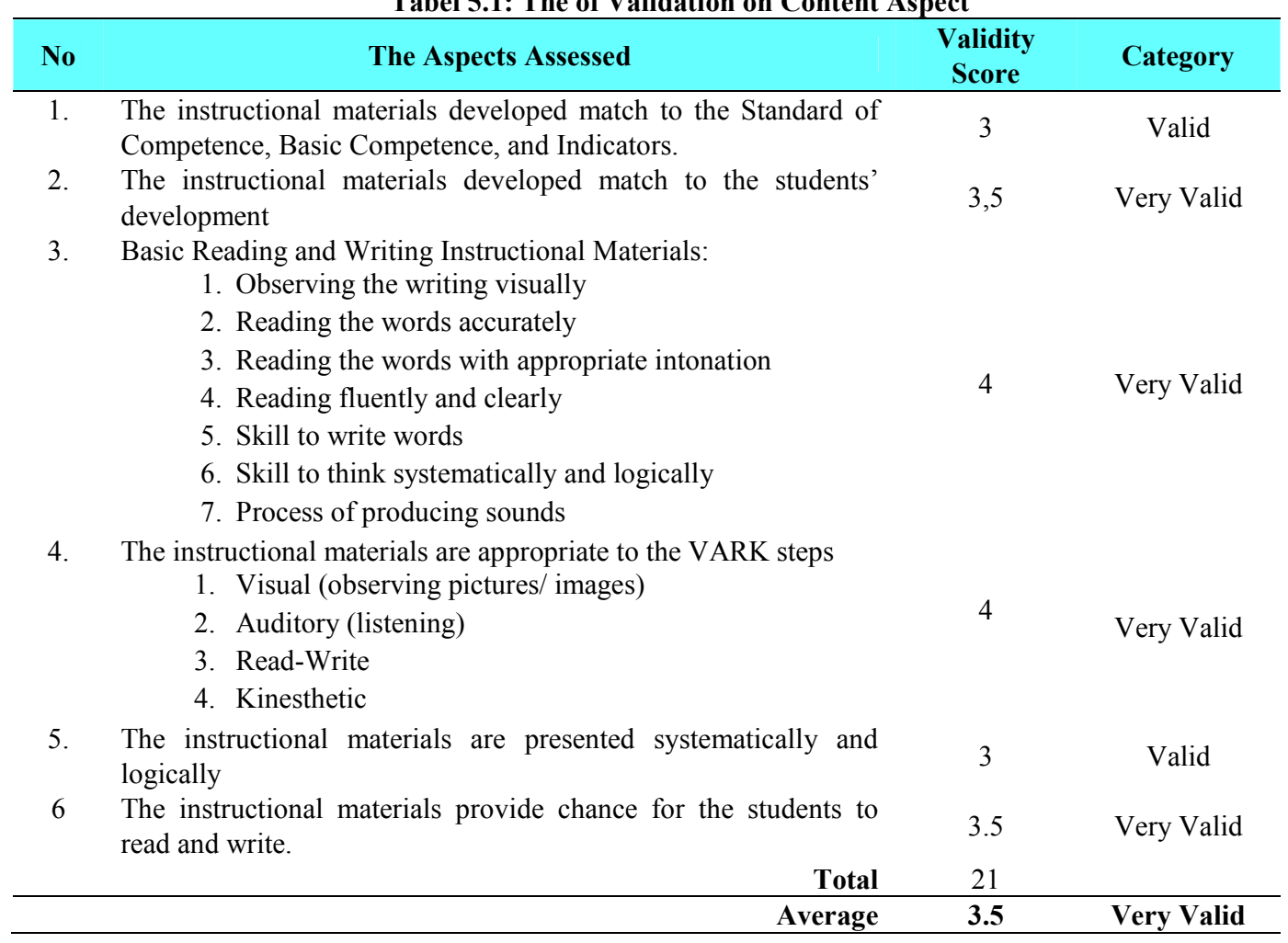

Based on the results of data analysis, it is revealed that the Lesson Plan developed needs to be revised and developed in accordance with the needs of the learning process of Basic Reading and Writing. The development is done by applying VARK model. Furthermore, the indicators formulated need to be adjusted to the Basic Competence. Related to the learning goals, they have to contain $\mathrm{ABCD}$ factors, including Audience, Behavior, Condition, and Degree. In addition, the learning stages of Basic Reading and Writing by using VARK model should match to the indicators specified. The evaluation guideline is written in details and in accordance with the students' ability. By considering all of the above aspects, the Lesson Plan developed is expected to be used effectively based on the Basic Reading and Writing learning needs in the 1 st grade

The Lesson Plan developed was validated by 2 expert validators. The results of the validation are presented in Table 5.1.

Based on the results of the Lesson Plan validation on content aspect, it is found that the

Tabel 5.2 The Result of Validation on Linguistic Aspect

\begin{tabular}{clcc}
\hline No & The Aspects Assessed & $\begin{array}{c}\text { Validity } \\
\text { Score }\end{array}$ & Category \\
\hline 1. & $\begin{array}{l}\text { Readability } \\
\text { 2. }\end{array} \begin{array}{l}\text { The clarity of the } \\
\text { information }\end{array}$ & 4 & Very valid \\
3. & $\begin{array}{l}\text { The appropriateness to } \\
\text { the grammatical } \\
\text { structure of Indonesian }\end{array}$ & 4 & Valid \\
4. $\begin{array}{l}\text { The use of effective and } \\
\text { efficient language Total } \\
\text { Average }\end{array}$ & 4 & 3.88 & Very Valid \\
\hline
\end{tabular}

average score of the materials, in general, is 3.5 (very valid). The table also presents that the appropriateness of the instructional materials design to the Standard of Competence, Basic Competence and indicators is 3, the appropriateness of the instructional materials design to the students' development is 3.5 , the appropriateness of the instructional materials to the VARK steps is 4 , the arrangement of the materials is 3 , and the chance given to the students to read and write is 4 . These results suggest that the instructional materials developed are valid in term of content.

In general, the validity score of the

Tabel 5.3 The Results of Validation on Presentation Aspect

\begin{tabular}{|c|c|c|c|}
\hline No & The Aspects Assessed & $\begin{array}{l}\text { Validity } \\
\text { Score }\end{array}$ & Category \\
\hline & $\begin{array}{l}\text { the achievement indicators } \\
\text { are formulated clearly }\end{array}$ & 3 & Valid \\
\hline 2. & $\begin{array}{l}\text { The materials are presented } \\
\text { systematically }\end{array}$ & 3 & Valid \\
\hline 3 & $\begin{array}{l}\text { The materials are } \\
\text { interesting and could } \\
\text { motivate the students }\end{array}$ & 4 & $\begin{array}{l}\text { Very } \\
\text { Valid }\end{array}$ \\
\hline 4 & $\begin{array}{l}\text { The materials enable the } \\
\text { interaction to take place } \\
\text { (provide stimuli and } \\
\text { responses) }\end{array}$ & 3,5 & $\begin{array}{l}\text { Very } \\
\text { Valid }\end{array}$ \\
\hline \multirow[t]{2}{*}{5.} & $\begin{array}{l}\text { The information provided is } \\
\text { complete } \\
\text { Total }\end{array}$ & $\begin{array}{c}4 \\
17,5\end{array}$ & $\begin{array}{l}\text { Very } \\
\text { Valid }\end{array}$ \\
\hline & Average & 3,5 & $\begin{array}{l}\text { Very } \\
\text { Valid }\end{array}$ \\
\hline
\end{tabular}


Tabel 5.4 The Result of Validation on Format Aspect

\begin{tabular}{clcc}
\hline No & \multicolumn{1}{c}{ The Aspects Assessed } & $\begin{array}{c}\text { Validity } \\
\text { Score }\end{array}$ & Category \\
\hline 1. & The font used is Footlight MT Light & 4 & Very valid \\
2. & $\begin{array}{l}\text { The size of the font for the content is 18, and for the cover } \\
\text { is } 48\end{array}$ & 4 & Very Valid \\
3. & The lay out represents the content of the book & 4 & Very Valid \\
4. & Illustration, images, and photos are clear. & 3,5 & Very Valid \\
5. & $\begin{array}{l}\text { The sources of illustration, images, and photos from which } \\
\text { they are taken are included }\end{array}$ & 3,5 & Very Valid \\
6. & $\begin{array}{l}\text { Illustration, images, and photos are about the students of } \\
\text { 7. }\end{array}$ & 3,5 & Very Valid \\
& $\begin{array}{l}\text { Indonesia } \\
\text { The design is fascinating and varied }\end{array}$ & 3,5 & Very Valid \\
\hline
\end{tabular}

instructional materials viewed from linguistic aspect is 3.88 (very valid). Based on the aspects assessed, it is figured out that the score of the readability is 3.5 , the clarity of the information is 4 , the use of correct grammatical structure of Indonesian is 4 , and the use of effective and efficient language is 4 . In other words, viewed from linguistic aspect, the instructional materials developed are very suitable for Elementary School students.

The above table presents that the validity score of the presentation aspect in general is 3.5 (very valid). The results indicate that the clarity of the achievement indicators, the materials organization, the attractiveness of the materials, and the completeness of the information given are applicable to the 1 st grade students of Elementary School.

Generally, the validity score of the instructional materials in term of format is 3,71 (very valid). Based on the format aspects assessed that include the font, lay out, illustration, images, photos, sources of the pictures used, and the design, it is found that the format of the materials is adjusted to the characteristics of the 1 st grade students of Elementary School.

The results of data analysis show that the validity score of the instructional materials is 3.64. Based on the category specified, the instructional materials could be regarded "very valid". The materials developed describe the agreement of all components, activities and concepts contained within. The agreement can be seen from the content, linguistic, presentation and format aspects of the materials. Generally, all of the components of the instructional materials are in accordance with the Regulation of the Ministry of Education and Culture Number 41 year 2017.

\section{CONCLUSIONS, IMPLICATIONS, AND SUGGESTIONS}

Based on the results of data analysis it is concluded that this research produces (1) indicators of competence achievement which is divided into two meetings in which the time allocated for each meeting is $3 \times 35$ minutes, (2) applicative guideline for the teachers to teach Basic Reading and Writing skills to the 1st grade students by using VARK model, (3) valid applicative guideline in the form of VARK model-based instructional materials (Lesson Plan) for teaching Basic Reading and Writing skills to the 1 st grade students.

Based on the results of the research, it is suggested to: (1) the educational practitioners to enrich the findings and the theory of Basic Reading and Writing for the 1st grade students of Elementary School by using VARK model, (2) the upcoming researchers to develop VARK model-based instructional materials for teaching Basic Reading and Writing skills and their applicative guidelines.

\section{REFERENCES}

[1] Fleming, N.D. 2001. Teaching and Learning Styles: VARK Strategies. New Zealand: Christchurch, N.Z. \& N.D. Fleming.

[2] Abidin, Yunus. 2012. Pembelajaran Bahasa Berbasis Pendidikan Karakter. Bandung: Refika Aditama.

[3] Hasrul. 2009. Pemahaman tentang Gaya Belajar. Jurnal MEDTEK, Vol. 1, No. 2, (http://ftunm.net/medtek/Jurnal\%20Medtek $\% 20$ Vo. $\% 2$ 01 No.2 Oktober\%202009/Hasrul.pdf, diakses tanggal 29 April 2016). 
[4] Huda, Miftahul. 2014. Model-model Pengajaran dan Pembelajaran. Yogyakarta: Pustaka Pelajar.

[5] Lisa, Kartono dan Sri Utami. 2015. Peningkatan Kemampuan Membaca dan Menulis Permulaan Menggunakan Metode SAS Siswa Kelas I Sekolah Dasar. Jurnal Jurnal Pendidikan dan Pembelajaran, (Online), Vol. 4. No. 11, (http://jurnal.untan.ac.id/index.php/jpdpb/articl e/view/12444/11306, diakses tanggal 29 April 2016).

[6] Miles, M \& Huberman, A.M. 1984. Analisis Data (Qualitatif). Terjemahan Tjetjep Rohandi Tohidi. 1992. Jakarta: Universitas Indonesia

[7] Saddhono, Kundaru dan St.Y.Slamet. 2012. Meningkatkan Keterampilan Berbahasa Indonesia. Bandung: Karya Putra Darwati.

[8] Setyosari, Punaji. 2010. Metode Penelitian Pendidikan dan Pengembangan. Jakarta: Kencana Prenada Media Group.

[9] Slamet, ST.Y. 2007. Dasar-dasar Pembelajaran Bahasa dan Sastra Indonesia di Sekolah Dasar. Surakarta: LPP UNS dan UNS Press.

[10] Sugiyono. 2009. Metode Penelitian Pendidikan Pendidikan Kuantitatif, Kualitatif, dan R\&D. Bandung: Alfabeta.

[11] Sukartiningsih, Wahyu. 2005. Peningkatan Kemampuan Membaca dan Menulis Permulaan Melalui Pembelajaran Konstruktivisme. Jurnal Pendidikan Dasar, (Online), Vol.6 No.2, (file:///C:/Users/x200m/Downloads/5031-73611-PB.pdf, diakses tanggal 29 April 2016).

[12] Taylor, Ronald. 2000. Assesment of Exceptional Students Uducational and Psychological Procedures.Florida: Florida Atlantic University.

[13]Uno, Hamzah B. 2007. Model Pembelajaran Menciptakan Proses Belajar Mengajar yang Kreatif dan Efektif. Jakarta: Bumi Aksara. 